Article received on August 25 2019

Article accepted on November $28^{\text {th }} 2019$

UDC: 785.11

78.071.1 Каломирис М.

\title{
Giorgos Sakallieros*
}

Aristotle University of Thessaloniki

School of Music Studies

\section{THE SYMPHONIC CONCERTO FOR PIANO AND ORCHESTRA (1935) BY MANOLIS KALOMIRIS: REAFFIRMING THE NATIONAL-IDEAL TOPOS THROUGH THE (OLD) WESTERN CANON ${ }^{1}$}

\begin{abstract}
Manolis Kalomiris's Symphonic Concerto for piano and orchestra (1935) consolidates the virtuosic piano performance and the complexity of romantic symphonic texture with the appearance of authentic Greek folk material, its westernized treatments, and symbolic self-references arising from the Greek National School principles. The work is critically examined through historical and analytical perspectives, aiming at a better understanding of the composer's aspirations expressing the indigenous artistic, cultural and political circumstances of the period when it was completed. Examples of the relative Greek and international "concertante" repertoire, from the late $19^{\text {th }}$ to the mid-20 $0^{\text {th }}$ century, are also taken into comparative consideration.
\end{abstract}

Keywords: Greek art music, piano concerto typology, modality, folk song, texture, variation, fugue, national identity, self-referential portrayal.

The cultivation of instrumental solo concerto was sporadic in Greek art music during the first half of the $20^{\text {th }}$ century, either in or beyond nationalistic

\footnotetext{
* Author contact information: sakallieros@gmail.com

1 An initial version of this paper, in Greek, was presented at the musicological symposium "Manolis Kalomiris and the Greek National School of Music" as part of the $14^{\text {th }}$ Hellenic Music Festival (Hellēnikes Mousikes Giortes), Music Library of Greece, Athens, 1-2 June 2018. Manolis Kalomiris's Papers are kept at the repository of the Manolis Kalomiris Society, National Conservatory of Athens. I would like to thank Myrto Economides, the society's Secretary for her generous help with the source material regarding the Symphonic Concerto.
} 
boundaries, in a manner conforming to chamber music ${ }^{2}$ and in contradistinction with the broader development of symphonic genres or opera. The Greek National School of Music, prevailing between 1910 and 1940, was affected by the political and cultural ideologies of the period like the irredentist theory of "Megalē Idea" (Great Ideal), ${ }^{3}$ of literary controversies like the "language question" 4 in Greek society, and also of the manifestation of the intricate nationalistic concept of "Greekness". The creative output of the majority of Greek composers of the period was centered on nationalistic operas bearing the strong symbolism of the folk narrative or historical figures and events, symphonic works of epic proportions with the participation of vocal soloists, choruses and narrators, as well as the solo song and choral repertory utilizing Greek poetry. The aforementioned trends are very discernible in the personality, ideology, and compositional style of Manolis Kalomiris (1883-1962), the leader of the Greek National School.

Having arrived in Athens from Kharkov in 1910, and after previous music studies in Vienna, Kalomiris quickly became a part of the Athenian musical establishment, immediately aligning himself with the leading political and literary figures of the period, taking a public stand in controversies like the "language question", and setting out to establish art-music creation envisioned through national ideology. ${ }^{5}$ His extensive writings (articles, music

2 Yannis Belonis, Chamber Music in Greece in the First Half of the 20 ${ }^{\text {th }}$ Century. The Case of Marios Varvoglis (1885-1967) [H

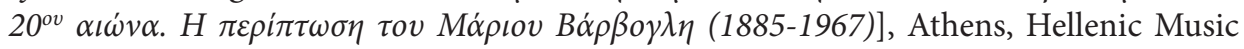
Centre, 2012, 79-82.

3 Proclaimed as a mid-19 ${ }^{\text {th }}$ century irredentist concept of Greek nationalism, Megale Idea expressed the longing to establish an expanded Greek state that would encompass all ethnic Greek-inhabited regions that still lived under Ottoman or other occupation. This concept dominated foreign policy and domestic politics of Greece right up till the catastrophic Asia Minor Campaign of 1919-22. See: Richard Clogg, A Concise History of Greece, Cambridge - New York, Cambridge University Press, 1992, 47-49.

4 The "language question" refers to the opposition between the supporters of the Greek people's everyday speaking idiom (demotic, demotikē) and the promoters of the language's purified form (kathareuousa), who eventually became an opposition between upper and lower social classes, liberals and conservatives, bourgeoisie and provincials, while involving the Greek Orthodox Church, literary circles and the press. The dispute lasted several decades. See: Philip Carabott, "Politics, Orthodoxy, and the Language Question in Greece: The Gospel Riots of 1901", Journal of Mediterranean Studies, 3/1, 1993, 117-138.

5 Yannis Belonis, “The Greek National Music School”, in: Katy Romanou (Ed.), Serbian and Greek Art Music, Chicago - Bristol, Intellect Books, 2009, 142-144; cf. Jim Samson, Music in the Balkans, Leiden, Brill, 2013, 302-313. 
reviews, public lectures, etc.) also aimed at collectively promoting his ideas, to the notion of constituting a musical and national-ideal topos. The manifestation of musical nationalism during the 1910s in Greece correlated music composition with literary movements and ideological vocabularies of the period, such as the notion of "ethnike psyche" (lit. transl. "national soul"), a term frequently found in Kalomiris's texts such as the programme notes of his first concert in Athens consisting entirely of his works (11 $1^{\text {th }}$ June, 1908). This text is acknowledged as the official manifesto of the Greek National School. ${ }^{6}$

Following the reformation of the programme of studies of the Athens Conservatory in 1891,7 piano became the leading instrument in music education amongst the bourgeois Athenians. As expected, piano students primarily focused on the basic $18^{\text {th }}$ - and $19^{\text {th }}$-century classics with which the first recital programmes of the period were also compiled. The broadening of the repertoire was enhanced with new Greek works from 1910 onwards by composers Manolis Kalomiris, Dimitri Mitropoulos, Mario Varvoglis, Dimitrios Levidis and Loris Margaritis, among others. Before long, Athenian audiences welcomed the solo concerto as an integral part of indigenous symphonic concert life, being fascinated by the first foreign piano virtuosos arriving in the Greek capital to perform with the Athens Conservatory Symphony Orchestra. After 1920, Greek soloists also initiated their own stage appearances, but it would take at least another decade for the first concertos for piano and orchestra by Greek composers to come to light.

Although few in number, these new concertos from the 1930s and '40s share a remarkable textural and stylistic diversity. ${ }^{8}$ Besides Kalomiris, Petros

6 The text is cited in Kalomiris's memoirs: Manolis Kalomiris, My Life and Art: Memoirs

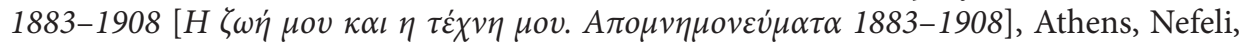
$1988,145-147$.

7 This reformation had more of a political than educational background and aimed at a programme of studies systematically organized according to a new Central European (predominantly German) orientation, which left behind the institution's South-European influences modelled on the $18^{\text {th }}$ and $19^{\text {th }}$ century Italian conservatories and philharmonic societies. See: Giorgos Sakallieros, "Perspectives of the Athenian Musical Life, 1870-1940", in Katrin Stoeck and Gilbert Stoeck (Eds.), Proceedings of the International Conference "Musik-Stadt. Traditionen und Perspektiven urbaner Musikkulturen", Leipzig, Gudrun Schroeder Verlag, 2012, Band 4, 97-98. Two early outcomes of this reformation were the Artist's Diploma recipients Dimitri Mitropoulos (piano, 1919) and Nikos Skalkottas (violin, 1920).

8 From 1930 to 1945, just nine piano concertos by Greek composers were completed. See: Ioannis Fulias, "Rena Kyriakou’s Concerto for Piano and Orchestra, Opus 18: Its History, 
Petridis (1892-1977) explored modality, "absolute" music and symphonic neoclassicism within his two piano concertos $(1934,1937)$, also responding to the nationalistic ideal though from a different angle than the National School's leader. Lila Lalaouni's (1918-1996) belated romantic touch, deprived of any nationalistic impulses, prevails in her Piano Concerto in E minor, a work concluded in the years of German Occupation in Greece (1942-43). Impressionistic nuances blended with elements of leisurely exoticism and neoclassical austerity are evident in the piano concertos of Rena Kyriakou (1917-1994, another woman composer and prominent piano soloist) and Yannis Andreou Papaioannou (1910-1989, one of the most important representatives of post-war modernism in Greece), both completed in 1940. However, the most solitary figure of the period, Nikos Skalkottas (1904-1949) was also the most productive one: his three dodecaphonic piano concertos (from 1931, 1938 and 1939, respectively) ${ }^{9}$ comprise just part of the six of his concertos including piano, and of thirteen in total from his entire oeuvre.

$* * *$

Both the autograph manuscripts of the full score and of the piano reduction of the Symphonic Concerto are preserved at the repository of the Manolis Kalomiris Society in Athens. The full score manuscript also exists in a revised, second autographic form in Kalomiris's own hand, which is more readable and includes conductor's notes. In the last page of this second autograph the date of completion is included: $18^{\text {th }}$ July, 1935 . The second autograph was completed on the $26^{\text {th }}$ September, 1937 and is used as source material for the present article. The concerto was dedicated to the memory of Calliope Kokkinos, the first woman who taught music theory at the National Conservatory of Athens (founded by Kalomiris in 1926) but unfortunately died at a young

a First Analytical Approach, a Critical Re-evaluation and an Attempt to Place the Work

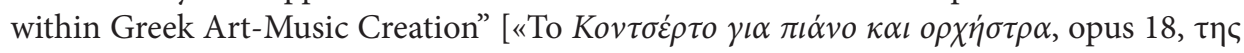

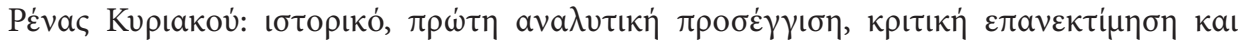

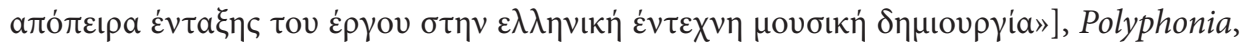
31, 2017, 64-69.

9 Nikos Skalkottas's Piano Concerto No. 1 from 1931 is both the first Greek and the first twelve-tone piano concerto in music history, preceding even the one by the composer's teacher, Arnold Schoenberg (from 1942). All three of Skalkottas's piano concertos were performed and recorded after 1950. For pre-war performances of the piano concertos of Kalomiris, Petridis, Lalaouni, and Kyriakou, see: Ibid., 67-68 (Table 2). 
age. The Symphonic Concerto is also one of the few works the composer labeled with an opus number.

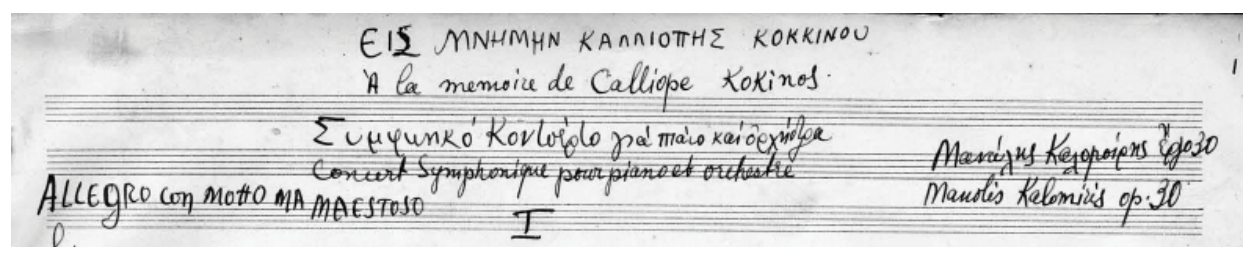

Image 1a. Part of the first page of the second autograph of Kalomiris's Symphonic Concerto for piano and orchestra, including title, dedication and opus number in both Greek and French (the Manolis Kalomiris Society - Reproduced with permission)

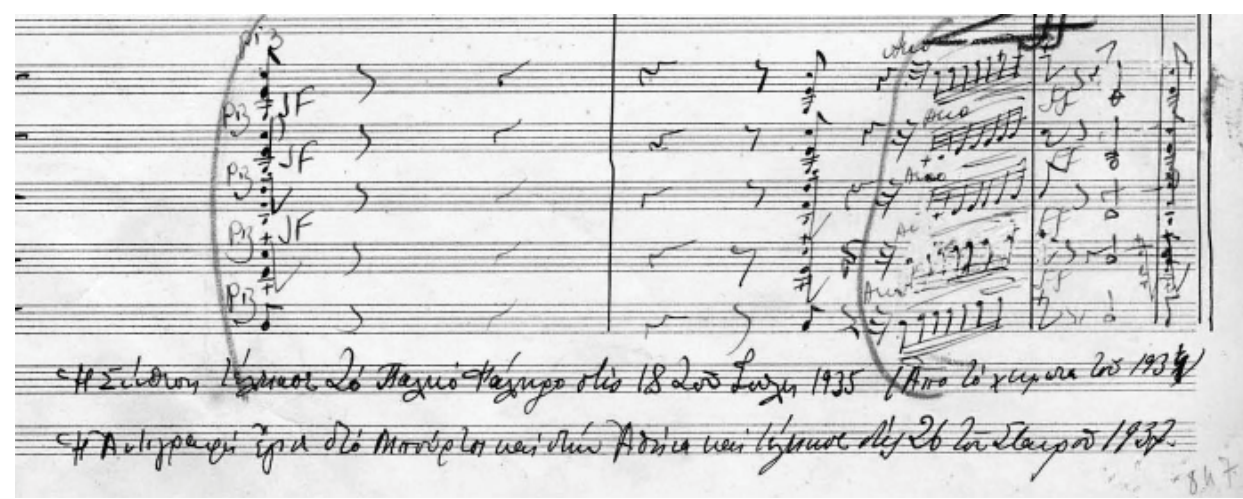

Image 1b. Part of the last page of the second autograph of Kalomiris's Symphonic Concerto (ending of the second movement), including the dates of the completion of the work and the completion of the second autograph (the Manolis Kalomiris Society - Reproduced with permission)

The first public performances of the work were given by different soloists within a two-month period. The Symphonic Concerto was premiered on the $5^{\text {th }}$ April, 1937 by Lila Lalaouni (the aforementioned composer of her own piano concerto) and the Athens Conservatory Symphony Orchestra with Philoctetes Economides as conductor. Shortly, on the $24^{\text {th }}$ May, 1937 a second performance was given by Krino Kalomiris, the composer's daughter, as part of the requirements for the degree of the Artist's Diploma at the National Conservatory of Athens. The orchestra was led by the Greek composer 
and conductor Leonidas Zoras. ${ }^{10}$ The work was also promoted abroad, e.g. in Berlin on the $5^{\text {th }}$ December 1938, again with Krino Kalomiris at the piano and Leonidas Zoras on the podium, conducting the Berlin Philharmonic Orchestra (though only the second movement was performed). ${ }^{11}$ More concerts followed, in Paris and Munich in $1953 .{ }^{12}$ The first studio recording was produced in the same year, again with Krino, this time with her father conducting the Greek National Radio Symphony Orchestra. ${ }^{13}$

In Kalomiris's Symphonic Concerto, the extensive symphonic development and the demanding piano part are in dialogue with the ubiquity of a Greek folk tune (throughout the second movement), its treatment by means of tonal and modal harmonization, variations and fugue, and the symbolic representation of self-references as a personified musical portrayal. In the first movement of the work, "Allegro con moto ma maestoso", the composer's eagerness to corroborate the canon, a sonata-allegro form, is hindered by his unconstrained melodic infatuation, a focus on the cantilena-like character of linear part-writing and a cyclic array of variational sections and modal transitions rather than a typical thematic development.

In the concert programmes of the $5^{\text {th }}$ April, 1937 and the $24^{\text {th }}$ May, 1937 there are unsigned musico-analytical notes which were definitely compiled under the composer's supervision. ${ }^{14}$ On the other hand, Kalomiris not only signs but also speaks in the first person about the long-term background of

10 The programme requirements of the National Conservatory of Athens for the Artist's Diploma in piano performance were impressively demanding at the time: Krino Kalomiris had to prepare two concertos with orchestra (the second one was César Franck's, Variations symphoniques) and 13 solo works (including five works by Greek composers).

11 For more details about the Berlin concert, including other Greek composers' works as well, see: Katy Romanou, "Exchanging Rings under Dictatorships", in: Roberto Illiano and Massimilliano Sala (Eds.) Music and Dictatorship in Europe and Latin America, Turnhout, Brepols, 2009, 50-55.

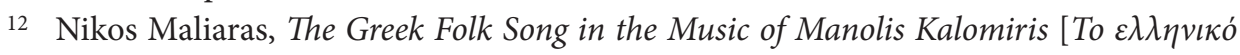

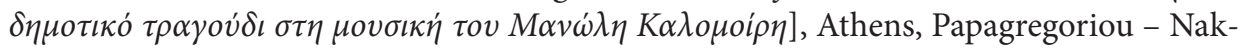
as, 2001, 57-58 (also fn. 135).

13 Kalomiris's concerto acquired a place in the indigenous repertoire and several performances were given over the years. Mary Chairogiorgou-Sigara, a fellow student of Krino Kalomiris, her talented pupil Dimitri Sgouros, Aris Garoufalis, a pianist widely identified with the oeuvre of Kalomiris, and more recently Vassilis Varvaresos, were all pianists closely associated with the Symphonic Concerto from the mid-1940s to the 2010s.

14 The concert programmes from both the 1937 performances are preserved at the repository of the Manolis Kalomiris Society. 
the Symphonic Concerto's creation in a separate text included in the $24^{\text {th }}$ May programme. This is a quite personal and emotional account of the composer, intrinsically going beyond the work's musical content. In the programme notes of the $5^{\text {th }}$ April, 1937 concert, the description of the thematic material of the first movement, accompanied by the requisite musical examples, consolidates a somewhat atypical sonata form with three distinctive themes, as 'an expansion of the classical form', according to the author's notes. ${ }^{15}$ In my opinion, these three thematic units in the first movement of the Symphonic Concerto are discernible; their inclusion into a sonata-allegro form is not, especially as regards the counterbalance of their motivic importance. ${ }^{16}$ Kalomiris mostly aims at a change of atmosphere through the contrasting mood of each theme against the other two. The principal thematic unit (A1), heroic and virile, is presented in full force from all four horns of the orchestra. ${ }^{17}$

Example 1. M. Kalomiris, Symphonic Concerto: Mvt. I. Thematic unit A1 (mm. 1-4)

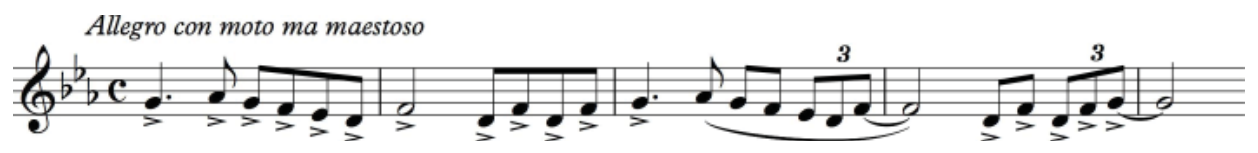

The A1 principal thematic unit is followed by a supplementary unit (A2) that first appears in m. 16; the A2 unit is adaptable in the motivic transformations and suitable for the alternation of sub-sections and for modal transitions.

Example 2. Extract of thematic unit A2 (mm. 23-28)

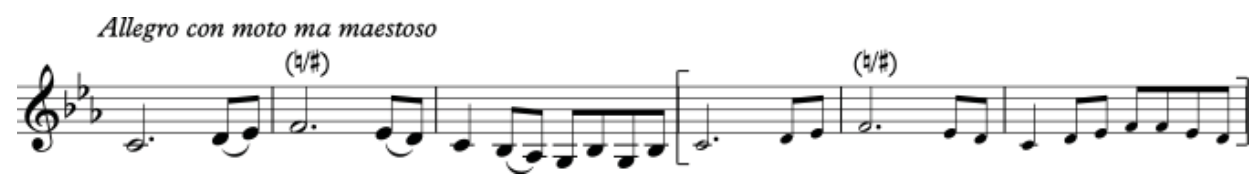

15 Unsigned programme notes from the concert programme of the Athens Conservatory Symphony Orchestra, $5^{\text {th }}$ April, 1937 [Manolis Kalomiris Society].

16 The same opinion is expressed by George Leotsakos in his unpublished essay "Sym-

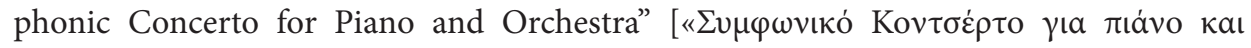

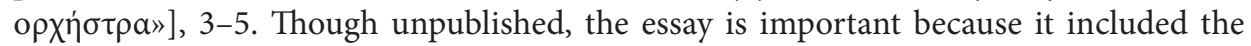
only musicological analysis on the first movement of the work so far (a copy is preserved at the repository of the Manolis Kalomiris Society).

17 Sound examples are available online at the official New Sound YouTube channel: https://youtu.be/gfXI5V5tjqU 
The transition of the thematic unit A1 to the upper chromatic tetrachord of $\mathrm{C}$ minor during the first orchestral tutti and after the conclusion of the introduction (mm. 1-38) is certainly evocative of the epic character of Kalomiris's symphonic and operatic works from the 1910s. The emphasis on the interval of the augmented second (A-flat - B) is generally a trademark of the Greek folk element for the composer and his first attempt here to label the western canon (form, thematic progress) with a national-identity sonic imprint.

Example 3. Modal transition of thematic unit A1 in the first orchestral tutti (mm. 39-46)

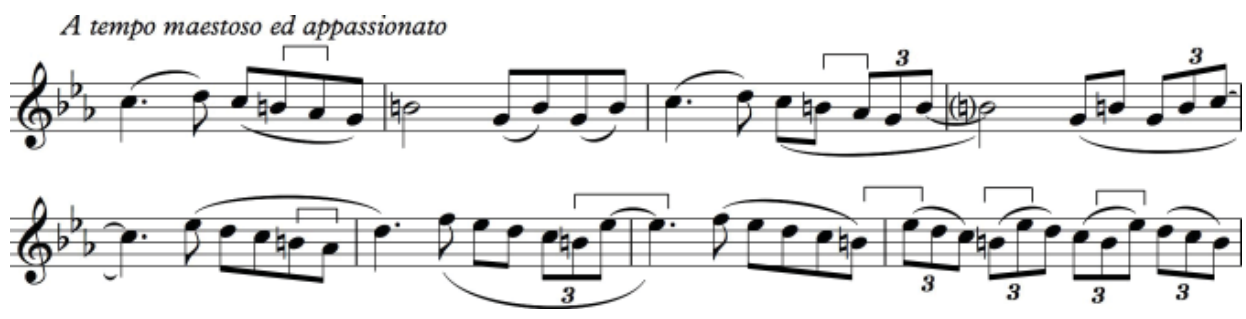

Regardless of the vagueness of the sonata-allegro configuration that Kalomiris has pursued so far, the resolution of the initial heroic section into a secondary, lyrical and pastoral, theme is inevitable. Conceived in G-dorian mode, thus emphasizing the relationship between a tonic and dominant key, thematic unit B conforms to the basic principle of the sonata form; a subordinate section of contrasting atmosphere and of concise development. Introduced by the flute, discreet and calm in its lower register, this melody definitely resembles the image of a shepherd surrounded by his flock and playing his pipe, a beloved representation of rural Greece in Kalomiris's works.

Example 4. Thematic unit B (flute 1, mm. 81-84)

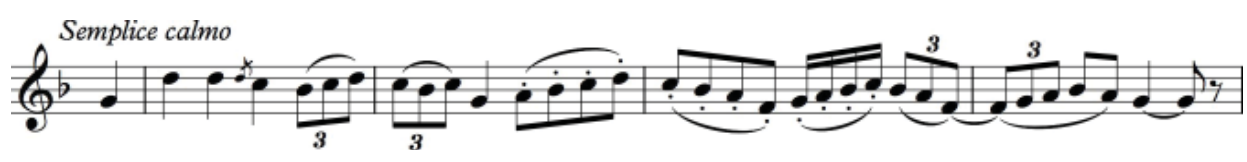

As far as the third thematic unit is concerned, this is actually an intervening short dance episode (entitled "Scherzando"), whose motivic content derives from the rhythmic transformation of the A2 thematic unit (so it should be labeled A2' and not C). Initially presented by the flute and celesta, it rapid- 
ly brings the element of folk-like instrumental performance to the forefront; the piano accompaniment clearly imitates the santouri, a Greek folk-music instrument very similar to the dulcimer.

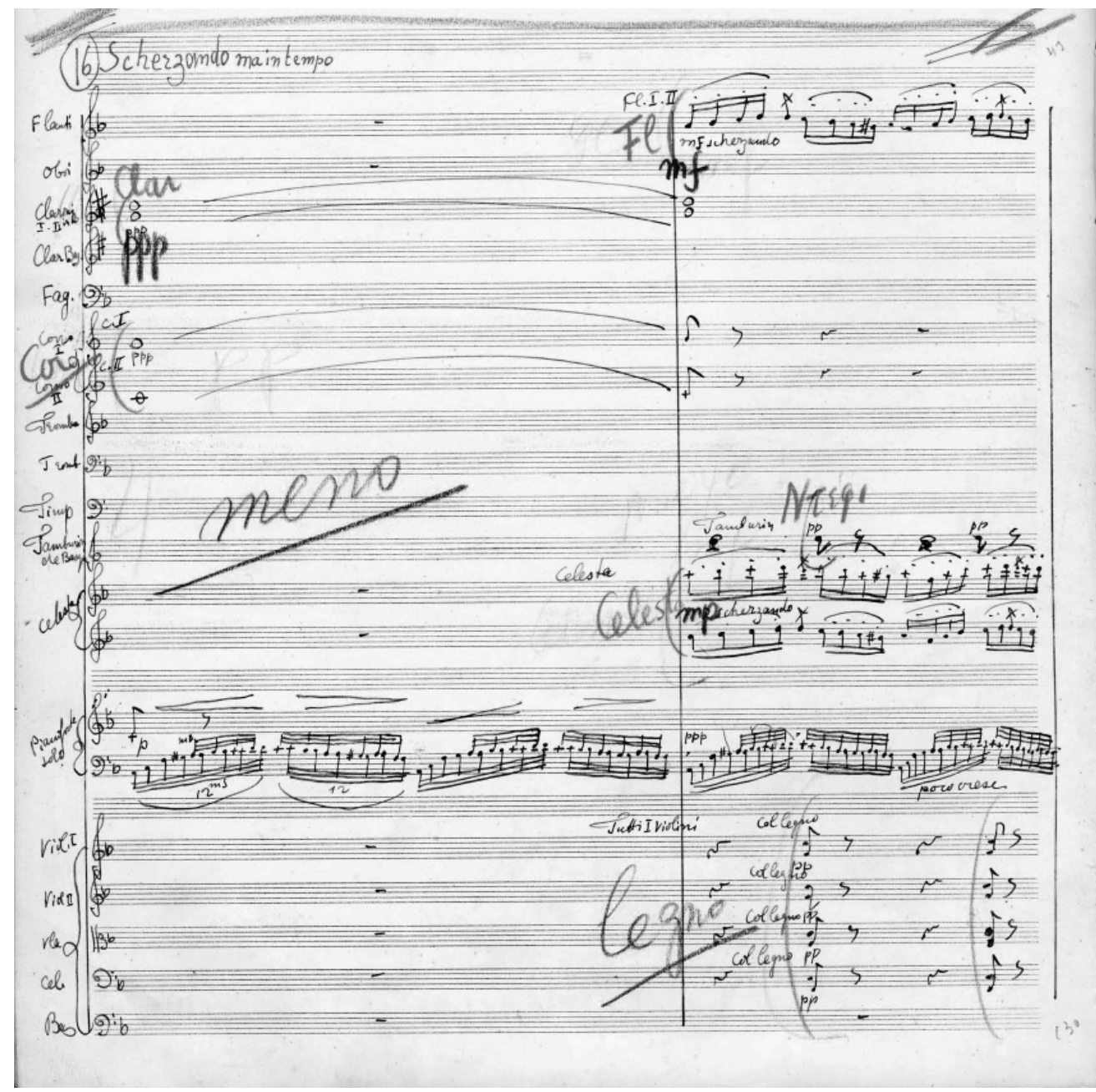

Image 2. Extract from the second autograph of Kalomiris's Symphonic Concerto (Mvt. I, mm. 130-31): The beginning of thematic unit A2', "Scherzando". See the idiomatic piano writing (the Manolis Kalomiris Society - Reproduced with permission)

The thematic transformation combined with Kalomiris's skillfulness on counterpoint brings impressive textural results in the cyclic character of the movement. The combination of rhythmic diminution (A1') of the principal 
theme (A1) into a dance-like tune is simultaneously cited with its full inversion (A1"). Within this very characteristic perspective of textural elaboration, the interval of the augmented second ( $\mathrm{C}-\mathrm{D}$-sharp) still remains pervasive. As George Leotsakos succinctly remarks: "It appears that Kalomiris is haunted by the principal theme". ${ }^{18}$

Examples 5a/b. Two transformations of the thematic unit A1 (A1'/rhythmic diminution, A1"/inversion), in contrapuntal combination (mm. 189-207)

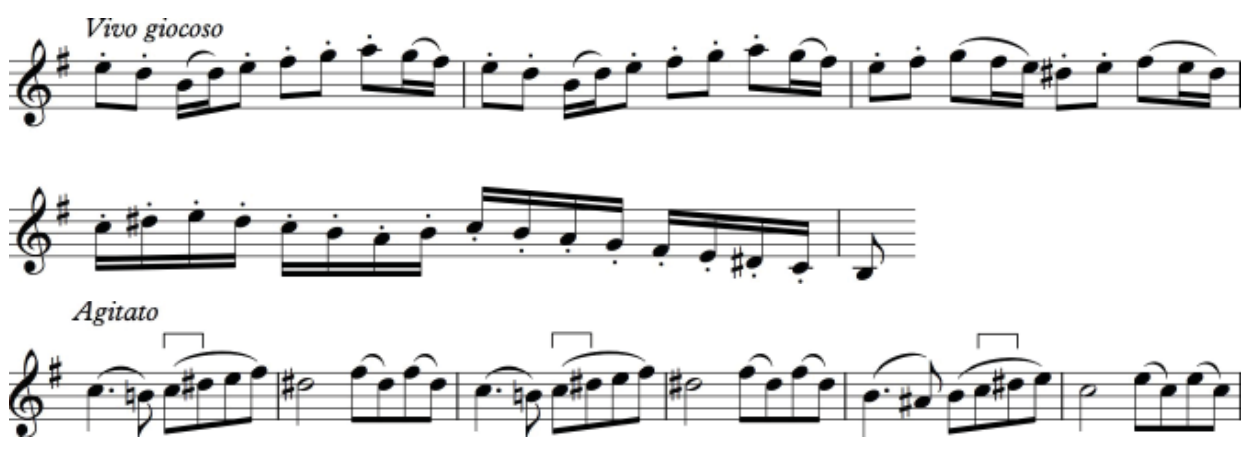

The basic layout of the 272 measures of the first movement of Kalomiris's Symphonic Concerto is shown in the following Table 1. Compared with the first movement of the composer's Trio for Piano, Violin and Cello (1921, constituting a more formalistic example of a sonata-allegro pattern), the concerto primarily incorporates the contrasting character of the primary and secondary themes and their contrapuntal juxtaposition rather than a concrete morphological layout through thematic elaboration. Kalomiris's obsession with thematic unit A1 brings the Symphonic Concerto closer to his Symphony No. 1 and its epic character. The first movements in both works share the principle of cyclically arraying thematically inter-connected sections through motivic variation, a common tonal basis ( $\mathrm{C}$ minor), and even the same introductory heroic gesture given by the horns. ${ }^{19}$ The announced (in the 1937 concert programmes' notes) sonata form is further contradicted in the following diagram, since the development middle section is dramatically condensed.

\footnotetext{
18 Ibid., 4.

19 Giorgos Sakallieros, “The Greek Symphony (1900-1950): Oscillating Between Greek Nationalism and Western Art-Music Tradition", in Nikos Maliaras (Ed.), Proceedings of the International Musicological Conference "The National Element in Music", Athens, University of Athens, Faculty of Music Studies, 2014, 37-38.
} 
Perhaps, a "truncated sonata-allegro form" hybrid would be more appropriate here. $^{20}$

Table 1. Manolis Kalomiris, Symphonic Concerto. Mvt. I. Allegro con moto ma maestoso: Structural diagram

\begin{tabular}{|c|c|c|}
\hline MM. & $\begin{array}{l}\text { Thematic } \\
\text { unit }\end{array}$ & Section \\
\hline 1 & A1 & $\begin{array}{l}\text { I. Exposition: Principal thematic unit (A1) - Virtuosic piano introduction } \\
\text { (conceived as joint ritornello) }\end{array}$ \\
\hline 16 & $\mathrm{~A} 2$ & Adjustable prolongation of A1 \\
\hline 39 & $\mathrm{Al}^{\prime}$ & Orchestral tutti with piano / $\mathrm{A} 1$ in the upper chromatic tetrachord of $\mathrm{C}$ minor \\
\hline 60 & $\mathrm{~A} 1+\mathrm{A} 2$ & Elaboration of thematic material, modal transition (E-dorian) \\
\hline 81 & $\mathrm{~B}$ & Secondary thematic unit (B, lyrical and pastoral) - motivic elaboration \\
\hline 115 & $\mathrm{~A} 1^{\prime}+\mathrm{B}$ & $\begin{array}{l}\text { II. "Development": }{ }^{21} \text { Thematic unit A1' in the upper chromatic tetrachord } \\
\text { (E-flat minor) - Transitional coda }\end{array}$ \\
\hline 130 & $\mathrm{~A} 2^{\prime}$ & $\begin{array}{l}\text { "Scherzando": Dance interlude (with elements of A2) / Folk-like performance } \\
\text { on piano }\end{array}$ \\
\hline 150 & A1 & $\begin{array}{l}\text { III. Recapitulation: Principal thematic unit }(\mathrm{A} 1)+\text { piano (as joint ritornello, } \\
\text { again) - Return to C minor }\end{array}$ \\
\hline 168 & - & Cadenza I \\
\hline 183 & A1'/" & $\begin{array}{l}\text { Introduction and double contrapuntal variation of A1 (diminution + inver- } \\
\text { sion) in a "Scherzando"-like sub-section (E minor) }\end{array}$ \\
\hline 208 & - & Cadenza II (heavily relying on A1) \\
\hline 234 & $\mathrm{~A} 1+\mathrm{A} 2$ & Closing zone: Final statement of A1 and A2 (piano and orchestra) in C minor \\
\hline 250 & A1" & Final coda \\
\hline
\end{tabular}

20 An alignment of Kalomiris's structural design of the first movement with "Type 1 Sonata" in the Hepokoski - Darcy categorization of the sonata forms, namely a binary type of sonata lacking the middle section of development, would not be very far-fetched [James Hepokoski and Warren Darcy, Elements of Sonata Theory: Norms, Types, and Deformations in the Late-Eighteenth-Century Sonata, Oxford - New York, Oxford University Press, 2006, 343-52]. Although this type is more preferred in slow and condensed movements of sonatas and concertos (or in overtures) the authors acknowledge that it can also be traced in large-scale and outer (fast) movements of such works (Ibid., 346347). Hepokoski's and Darcy's detailed categorizations may be adjustably implemented into a wide range of $20^{\text {th }}$ century music, e.g. Skalkottas's concertos.

21 As already mentioned, this is a very concise transitional section and not a fully-fledged middle part of a ternary sonata-allegro structure. 
The second movement of the concerto is entitled "Variations, Fugue and Finale on a Greek folk tune" and has attracted the interest of musicologists more than the first, ${ }^{22}$ not only because of Kalomiris's efforts to reconcile the authentic Greek melody with the western canon (variations, fugue) but also due to the history of its conception and creation that the composer himself describes in detail in the concert programme of the $24^{\text {th }}$ May, $1937 .{ }^{23}$ Kalomiris refers to the folk melody of "Ho Lyngos, ho leventēs, o archilēstēs" (lit. transl. "Lynx the Gallant") as a musical evocation he was consistently meeting with throughout his life; from Smyrna, where his grandmother had sung it to him; to westernized transcriptions for male voice and piano, like Stefanos

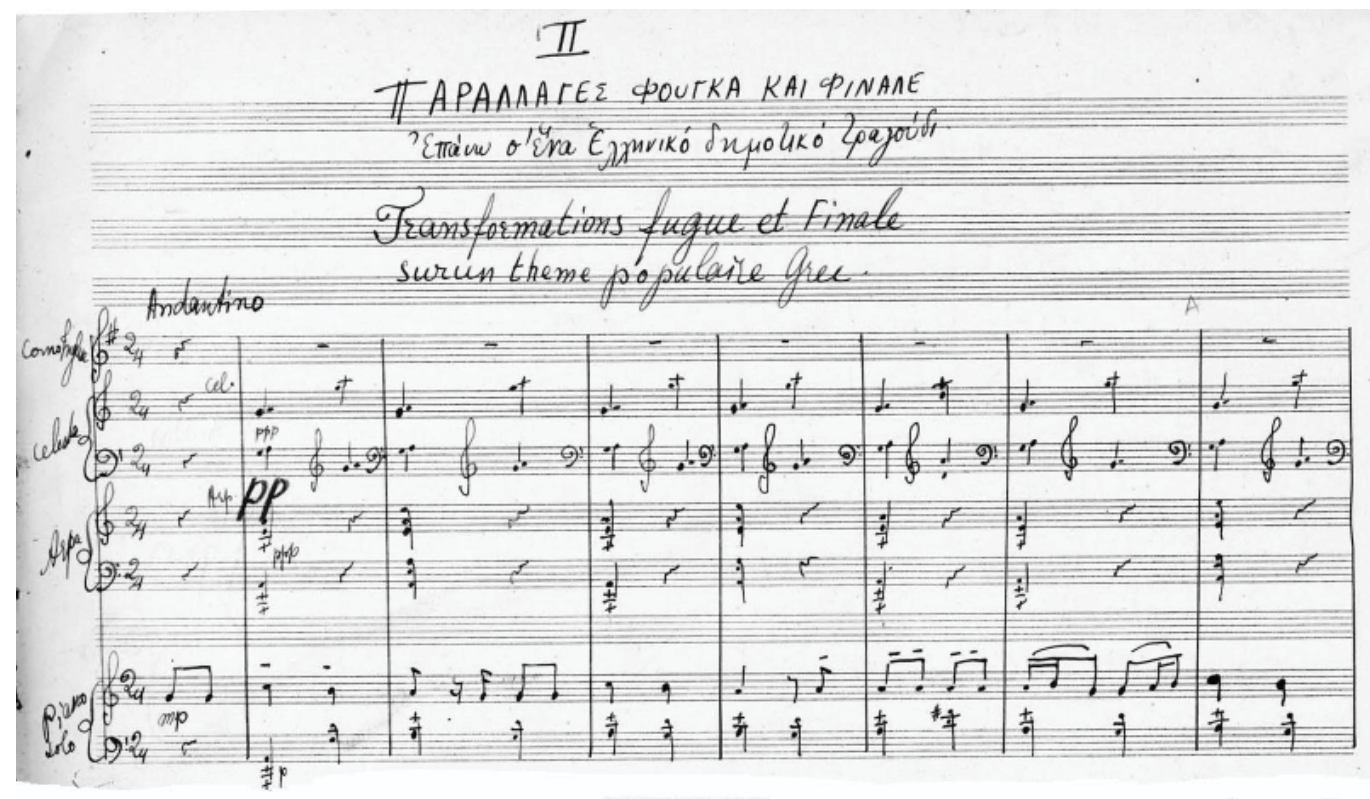

Image 3. Extract from the second autograph of Kalomiris's Symphonic Concerto: Mvt. II, beginning (the Manolis Kalomiris Society - Reproduced with permission)

22 Cf. Nikos Maliaras, “The Greek Folk Song...”, op. cit, 57-58, 213-224 and George Leotsakos, “The Symphonic Concerto...”, op. cit., 5-8.

23 This text was also slightly revised and included in the $7^{\text {th }}$ January, 1955 issue of the newspaper Ethnos (where Kalomiris was a music critic for 32 years) for the upcoming performance of the Symphonic Concerto on the $9^{\text {th }}$ January, 1955. It is also partly included and commented upon in: Olympia Frangou-Psychopedis, The National School of

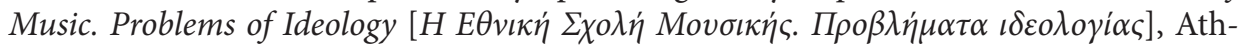
ens, Foundation for Mediterranean Studies, 1990, 80-81. 
Valtetsiotis's version performed by lyric male singers (Aramis, Yannis Angelopoulos, Nikos Moschonas); from the years of his studies in Vienna where he came up with the idea of elaborating "Lyngos" into a set of variations and fugue modelled on Max Reger who he had personally met and deeply admired; ${ }^{24}$ and finally to the years of maturity when he conceived these variations as a whole movement of a piano concerto.

The folk melody of "Lyngos" comprises a 10-measure pattern that undergoes variform elaboration through a series of unnumbered variations and resulting in a tortuous and dramatic fugue. Actually, Kalomiris prefers the term "transformations" instead of "variations" (although he also uses the Greek term for "variations": «ПАРА $\Lambda \Lambda$ АГЕ $\Sigma$ », see Image 3), exactly as he does in the second movement of his 1921 Piano Trio, evidencing the developmental fluidity that characterizes the second movement of the Symphonic Concerto, open to multiple analytical commentary. The initial statement of the "Lyngos" tune by the piano is simple, in A-dorian mode and within an impressionistic atmosphere to the presence of harp and celesta.

Example 6. M. Kalomiris's Symphonic Concerto. Mvt. II: Thematic material of the Greek folk song "Ho Lyngos, ho leventēs, o archilēstēs" (mm. 1-10)

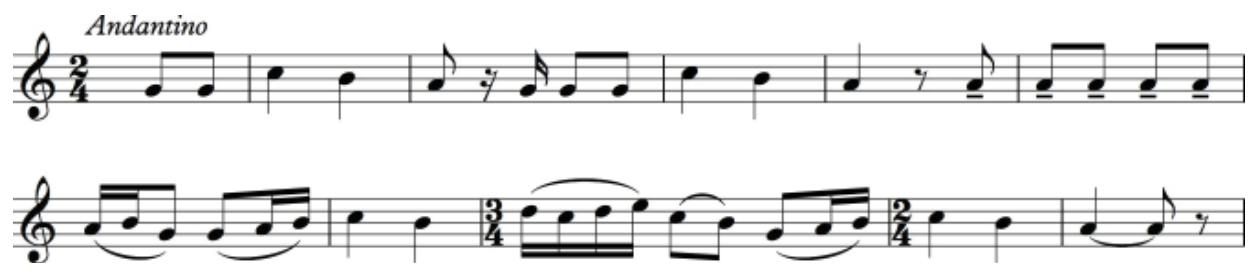

The fugue represents the dramatic culmination of the variations' section, authenticating the Baroque canon under a late-romantic Regerian perspective. It also comprises the preparatory section that links the second movement with the first. The principal fugal subject clearly evokes the "Lyngos" tune.

Example 7. The principal fugal subject (first stated in mm. 354-357)

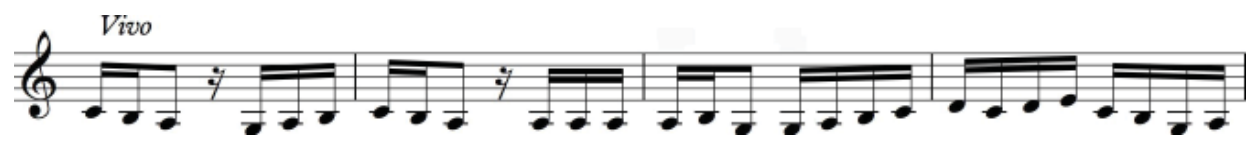

24 Kalomiris, My Life and Art, op. cit. 80-82. 
The fugal development leads to the appearance of the principal subject in inversion (mm. 400-403), combined with its ordinary form through Stretto sections, augmentation and diminution. A secondary fugal subject then appears, along with the principal one, in order for a double-fugato section to be developed. This second subject is a direct derivative of the A1 principal thematic unit of the first movement. This is Kalomiris's way of gradually affirming the cyclic character of the whole work by interlocking the thematic material from both movements into the same section through complex counterpoint. The first four-part exposition of the secondary fugal subject occurs in mm. 452-474 and is stated by each principal of the woodwind section.

Example 8. The secondary fugal theme (mm. 452-456)

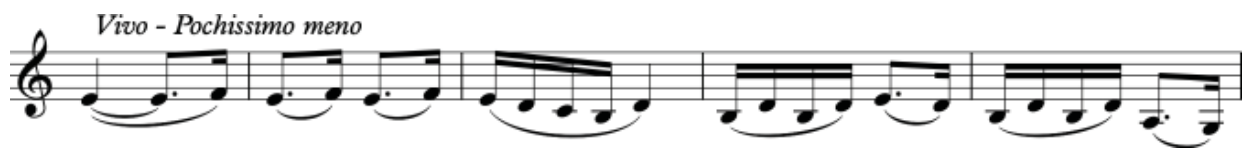

The second movement of the Symphonic Concerto spans 575 measures and the variations alone (without the fugue) last 353 measures. This is the lengthiest variations movement in all of Kalomiris's output and can be compared only with works like the orchestral Variations and Fugue on a Greek Folk Song (1940) by Antiochos Evangelatos, the variations on the Byzantine hymn "Tē hypermachō" in the finale of Petros Petridis's Symphony No. 4 (1942), or the atonal Eight Variations on a Greek Folk Tune (1938) for piano trio by Nikos Skalkottas that also end with a fugue. ${ }^{25}$ Kalomiris's refraining from strictly numbering his "Lyngos" variations indicates his effort to create a kaleidoscopic alternation of autonomous musical images, each one with its own texture and sometimes in significantly contrasting emotional nuances.

The rhapsodic style of the musical text in the variations negates homogeneity, provoking the listener to freely associate texture with sentiment. The rhythmic clarity of variations 1, 2 and 4 leads to an improvisatory rendition of "Lyngos" material in Nos. 3 and especially 5; a vivid "sousta" (lively folk dance from the isle of Crete) intervenes throughout the variations (like the "Scherzando" section of the first movement), forming small dance episodes that dissolve in the last variation, a slow haunting section of esoteric mysticism where the "Lyngos" tune is contrapuntally deployed in a two-part can-

25 Skalkottas also used the melody of "Lyngos" in his famous 36 Greek Dances for orchestra (1931-36, Series II, No. 12 "Peloponissiakos II"). 
on by the piano. In Kalomiris's Symphonic Concerto, the transformations of the folk material build up consecutive sonic impressions sometimes distantly echoing their source.

Table 2. M. Kalomiris, Symphonic Concerto. Mvt. II: Transformations (Variations) on the Greek folk tune "Ho Lyngos, ho leventēs, o archilēstēs". Structural diagram

\begin{tabular}{|c|c|c|}
\hline MM. & Section & Elaboration \\
\hline 1 & Theme & Greek Folk tune by the piano \\
\hline 15 & 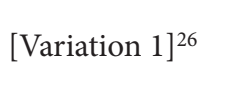 & $\begin{array}{l}\text { Partial rendition of the folk tune by the oboe, improvisation-like } \\
\text { accompaniment by piano and celesta }\end{array}$ \\
\hline 28 & [Variation 2] & $\begin{array}{l}\text { Folk tune in 3/8-meter version, more intensively from m. } 47 \\
\text { (evolved into a dance-like dotted rhythmic pattern) }\end{array}$ \\
\hline 73 & [Variation 3] & $\begin{array}{l}\text { Calm, pastoral rendition of the folk tune by the English horn, } \\
\text { followed by the piano }\end{array}$ \\
\hline 89 & [Variation 4] & $\begin{array}{l}\text { Contrasting appearance of the "Lyngos" theme in a lively } 2 / 4 \text { - } \\
\text { metre version by the woodwind section }\end{array}$ \\
\hline 115 & [Variation 5] & $\begin{array}{l}\text { Narrative character of the folk tune ("quasi recitativo) by clarinet } \\
1 \text {, flute } 1 \text { and the English horn; harp and celesta contribute to the } \\
\text { impressionistic atmosphere }\end{array}$ \\
\hline 155 & [Variation 6] & $\begin{array}{l}\text { Vivid dance-like rendition of the folk tune by the piano (a Cretan } \\
\text { "sousta" dance in } 2 / 4 \text { with dotted rhythmic pattern); impressive } \\
\text { statement by trumpet } 1 \text { in mm. 171-178 }\end{array}$ \\
\hline 179 & $\begin{array}{l}\text { Dance interlude } \\
\text { (as intervention) }\end{array}$ & $\begin{array}{l}\text { Development of Cretan "sousta" pattern as basis of linear and } \\
\text { contrapuntal development; contrasting dynamics and colourful } \\
\text { instrumental participation }\end{array}$ \\
\hline 306 & [Variation 7] & $\begin{array}{l}\text { The "Lyngos" theme in the low strings; the piano develops a two- } \\
\text { part canon resulting in a chorale-like chordal sequence (mm. } \\
322-325,343-353)\end{array}$ \\
\hline
\end{tabular}

The fugue is also the culminating point of Kalomiris's contrapuntal capabilities, already demonstrated at the end of the first movement. The principal

${ }^{26}$ I proceeded to an indicative numbering of the variations for the purpose of analysis and easier transition through sub-sections. The variations' openness to multiple analytical commentary is proved by the assertions of the other two musicologists that have analyzed the work: Nikos Maliaras recognizes nine variations (op. cit., 215-221) while George Leotsakos comes up with seven but in a different division of measures and sub-sections than I do (op. cit. 6-8). 
fugal subject, final transformation of the "Lyngos" folk song, is undoubtedly manipulated under the late 17th-century contrapuntal canon; answer in the upper 5th, countersubject accompaniment, four-part exposition, subject entries in Stretto, in augmentation, in diminution, in inversion, and alternation of subject entries with contrapuntally milder episodes. A secondary fugal subject, deriving from the A1 principal thematic unit of the first movement, begets maximum complexity of the contrapuntal progress, being involved in a double fugato with the principal fugal subject that foretells the Finale section.

The concluding Finale is actually both a recapitulation of the first movement and, at the same time, a verification of the cyclic structure of the Symphonic Concerto. The total recall of the A1 thematic unit from Movement I contrapuntally interweaves with the principal fugal subject of Movement II, resulting into a similar juxtaposition of the secondary fugal subject with the "Lyngos" folk tune and leading to a dazzling coda.

Table 3. M Kalomiris, Symphonic Concerto. Mvt II: Fugue and Finale structural diagram

\begin{tabular}{|c|c|c|}
\hline MM. & Section & Elaboration \\
\hline \multicolumn{3}{|c|}{ Fugue } \\
\hline 354 & Exposition & $\begin{array}{l}\text { - Statement of principal fugal subject } \\
\text { - Four-part exposition with additive subject entries } \\
\text { - Subject entries (Stretto, augmentation, diminution) }\end{array}$ \\
\hline 394 & Episode I & $\begin{array}{l}\text { Elements of principal subject, combination of imitative with } \\
\text { free counterpoint }\end{array}$ \\
\hline 400 & $\begin{array}{l}\text { Counter-exposition } \\
\text { I }\end{array}$ & Entries of principal subject in inversion \\
\hline 424 & Episode II & $\begin{array}{l}\text { Elements of principal subject, in milder contrapuntal elabo- } \\
\text { ration }\end{array}$ \\
\hline 430 & $\begin{array}{l}\text { Counter-exposition } \\
\text { II }\end{array}$ & $\begin{array}{l}\text { Principal subject in ordinary and inverted form, use of } \\
\text { Stretto followed by a short free counterpoint section (as co- } \\
\text { detta) }\end{array}$ \\
\hline \multirow{3}{*}{452} & \multirow{3}{*}{$\begin{array}{l}\text { Counter exposition } \\
\text { III }\end{array}$} & - First statement of secondary fugal subject \\
\hline & & $\begin{array}{l}\text { Double fugato section with principal and secondary } \\
\text { subjects in complex elaboration (Stretto, inversion) }\end{array}$ \\
\hline & & - Coda (mm. 508-515) \\
\hline \multicolumn{3}{|c|}{ Finale } \\
\hline 516 & A tempo Maestoso & $\begin{array}{l}\text { Contrapuntal dialogue between principal fugal subject and } \\
\text { A1 thematic unit of Mvt. I (with return to C minor) }\end{array}$ \\
\hline
\end{tabular}




\begin{tabular}{|l|l|l|}
\hline 532 & Con brio & $\begin{array}{r}\text { - Reinstatement of dance interlude from variations' sec- } \\
\text { tion (Cretan "sousta") } \\
\text { - Prolongation, including the dance-like transformation } \\
\text { of the A1 thematic unit from Mvt. I }\end{array}$ \\
\hline 554 & A tempo Maestoso & $\begin{array}{l}\text { Contrapuntal dialogue between the "Lyngos" folk tune and } \\
\text { the secondary fugal subject }\end{array}$ \\
\hline 563 & Piu agitato & $\begin{array}{l}\text { Coda: Final statement of the "Lyngos" folk tune in its origi- } \\
\text { nal form (by the strings) and virtuosic passages by the piano } \\
\text { culminating in the forceful cadential ending }\end{array}$ \\
\hline
\end{tabular}

\section{$* * *$}

But why is this piano concerto labeled as "Symphonic"? Kalomiris clarifies his compositional intentions in the $24^{\text {th }}$ May, 1937 programme:

This concerto mainly expresses the composer's inner emotions and aims less at a pianistic show off. The orchestra is equally important to the piano. However, one should neither assert that the piano part is limited and deprived of high-performance demands, nor that this work is a symphony or a symphonic poem with piano obbligato. ${ }^{27}$

Although the composer has not assigned too many sections of the piano emphatically in the forefront, an appropriate performance of the piano part requires the highest virtuosity available in order for the soloist to cope with all the octaves, arpeggios, scales, block chord sequences and tremolos Kalomiris has meticulously written down. A notion of unconstrained exuberance in the piano texture may be comprehended as fitting to the rich orchestra-

27 Kalomiris's indirect relegation of modernism does not make him unaware of the music of his time (e.g. Skalkottas's works which he opposed) but rather defensive against the criticism about his own works that was often harsh. The musicologist and music critic Minos Dounias released a negative review for the performance of Symphonic Concerto on $9^{\text {th }}$ January, 1955 (Kathimerini, 12 ${ }^{\text {th }}$ January, 1955). For the exact same performance Kalomiris received two extremely supportive letters by the composer, musicologist and philosopher Agamemnon Mourtzopoulos (on the $9^{\text {th }}$ and $12^{\text {th }}$ January, 1955), the second one aiming at literally deconstructing Dounias's review. See: Byron Fidetzis, "A Correspondence and a Musicological Sketch. Manolis Kalomiris and the Thinker, Composer

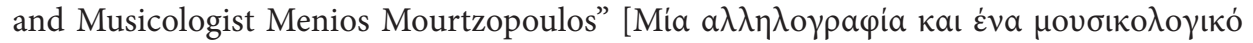

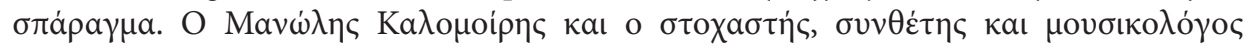

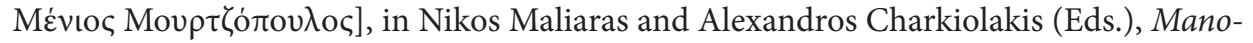
lis Kalomiris. 50 Years Later, Athens, Fagotto Books, 2013, 259-266. 
tive palette, a combination contributing to the "symphonic" character of the work. The orchestral writing is colourfully inventive, in both tutti sections and accompaniment parts by the strings, harp and celesta, or in the solo passages by the woodwinds. The harmonic language oscillates between progressions of modal clarity or tonal functionality and more complex or moderately dissonant chordal structures. As regards the national-identity topos, issues of folk-music tradition, conservatism and modernism are intermingled in the composers's argument:

The music I have imagined for my concerto, as in most of my other works, presupposes a full understanding of the rhythms and modes of the Greek Folk Muse [....] Is this work modern or not? I don't know and I care less. To me there are not modern or conservative works, there are only works of honest intentions and of artificial, false pretenses. There are works that have something to say and works that are empty though daubed with a splash of modernist paint.

The position of Kalomiris's Symphonic Concerto in the concertante repertoire of his time, or a bit earlier, is not easy to classify and may suggest unexpected associations. Perhaps, the composer aimed at dissociating himself with works such as Symphonie Concertante op. 60 for piano and orchestra (1932) by Karol Szymanowski, also known as the latter's Symphony No. 4. On the other hand, Kalomiris's turn to French music and culture in the 1920s and $30 \mathrm{~s}^{28}$ brings to mind possible influences by works like Vincent d'Indy's, Symphonie sur un Chant Montagnard Français [Symphony on a French Mountain Air] op. 25 for piano and orchestra (1886), a composer, indirectly present at the Athens Conservatory, through his student Armand Marsick, the teacher of Dimitri Mitropoulos. Marsick introduced and continued to use d'Indy's textbook Cours de composition musicale at the conservatory during the same period Kalomiris taught there (1910-1918). ${ }^{29}$ In César Franck's, Variations symphoniques (1885), for piano and orchestra the characteristic interval of augmented second in the piano introduction (mm. 5-9) definitely refer

\footnotetext{
28 Belonis, “The Greek National Music School”, op. cit., 135-136.

29 Giorgos Sakallieros, "Imitative Counterpoint in the Works of Dimitri Mitropoulos.

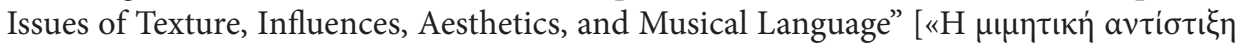

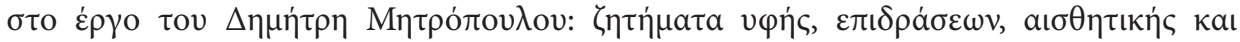

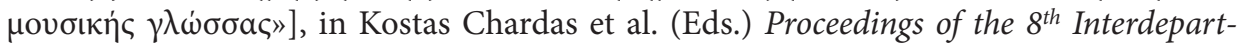
mental Musicological Conference "Effetcs and Interactions", Thessaloniki, Hellenic Musicological Society, 2019, 244-246 [available online: https://musicology.mus.auth.gr/ wp-content/uploads/2019/04/ConfProc2016.pdf ]
} 
to chromatic modal tetrachords, also widely employed by Kalomiris. Let us not forget that Franck's Variations symphoniques was the second concertante work in Krino Kalomiris's Artist Diploma programme of 1937, along with her father's Symphonic Concerto. The belated romantic impulses of the pianistic art of Serge Rachmaninoff are evident in Kalomiris's concerto, mainly in the Final Coda of the first movement. ${ }^{30}$ Russian influences also include a reference to Aleksandr Glazunov's Piano Concerto No.1 in F minor, op. 92. ${ }^{31}$ But before stylistic belatedness and frank conservatism are fervently accredited to the Greek composer, let us just consider for a moment a case like Béla Bartók's Piano Concerto No. 3 (1945). In the third movement, Bartók introduces a purely folk-like thematic unit (mm. 141-174) followed by a fugato section (mm. 228-343), fully compatible with the "old" (contrapuntal) canon and in certain ways correlating to Kalomiris's second movement of the Symphonic Concerto. Finally, the only work of the 1930s literature bearing the same title as Kalomiris is the three-movement Symphonic Concerto for piano and orchestra by the famous conductor Wilhelm Furtwängler. It was premiered by the pianist Edwin Fischer and the Berlin Philharmonic in October 1937, with the composer as conductor, preceding the aforementioned German premiere of Kalomiris's Symphonic Concerto at the German capital and by the same orchestra, by just one year. ${ }^{32}$

In conclusion, Kalomiris's Symphonic Concerto aesthetically identifies with the composer's earlier apprehension of the notion of "national identity" in Greek art music. Concerning belatedness, one should not neglect that after the experimentations and the spirit of multi-cultural freedom that prevailed in the early inter-war years in Europe, the 1930s arrived as a period

30 The final measures of this section (mm. 244-249) discreetly echo Rachmaninoff's Piano Concerto No. 2, also in C minor, and especially its closing section of Mvt. I, mm. $245-260$.

31 Ioannis Fulias, “Rena Kyriakou's Concerto for Piano and Orchestra..., op. cit., 68-69.

32 The generic title is accredited to the composer Henri Charles Litolff (1818-1891) who wrote five piano concertos, each one entitled Concerto symphonique. All cast in four movements, including a scherzo, they certainly influenced Brahms into pursuing a similar four-movement structure in his Piano Concerto No. 2, op. 83, while other attempts on bringing closer the genres of concerto and symphony had already occurred in the piano concertos of Liszt and also in the, literally unknown, eight piano concertos of Ignaz Moscheles (1794-1870) [Stephan D. Lindeman, “The Nineteenth-Century Piano Concerto", in: Simon P. Keefe. The Cambridge Companion to the Concerto, Cambridge, Cambridge University Press, 2005, 99-103, 111-112. 
of nationalistic resurgences and even authoritarian regimes throughout the continent. ${ }^{33}$ The "Lyngos" folk tune, besides its immediate reference to Greek musical tradition, is also an autobiographical leit-motif of Kalomiris, following him all his life. It takes an art form at the composer's later age, through a grand-scale symphonic work where the piano is the protagonist. Hence, both the piano and the "Lyngos" motif symbolically represent the composer himself, ${ }^{34}$ in an updated national-identity topos where historical memory becomes personal memory, and collective context becomes individual context. Such an assertion primarily concerns the historical time of its occurrence (e.g. Kalomiris in the mid-1930s), but it can also be varyingly deciphered within the perpetual dimensions of musical time.

\section{Works cited}

Belonis, Yannis: “The Greek National Music School”, in: Katy Romanou (Ed.), Serbian and Greek Art Music. Chicago Bristol: Intellect Books, 2009, 127-161.

---: Chamber Music in Greece in the First Half of the $20^{\text {th }}$ Century. The Case of Marios Var-

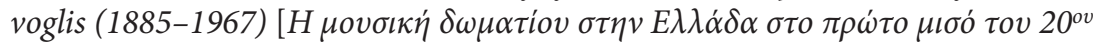

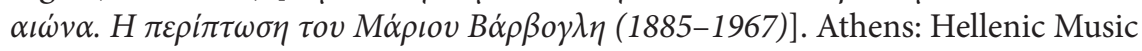
Centre, 2012.

Block, Adrienne Fried: “A 'Veritable Autobiography'? Amy Beach's Piano Concerto in C-sharp Minor, op. 45", The Musical Quarterly, 78/2, 1994, 394-416.

Carabott, Philip: "Politics, Orthodoxy, and the Language Question in Greece: The Gospel Riots of 1901", Journal of Mediterranean Studies, 3/1, 1993, 117-138.

Clogg, Richard: A Concise History of Greece. Cambridge New York: Cambridge University Press, 1992.

Fidetzis, Byron: "A Correspondence and a Musicological Sketch. Manolis Kalomiris and the Thinker, Composer and Musicologist Menios Mourtzopoulos Mourtzopou-

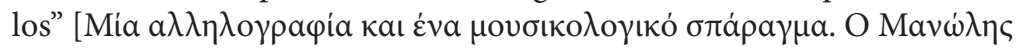

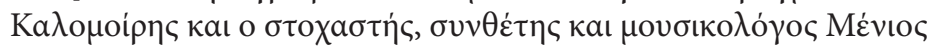

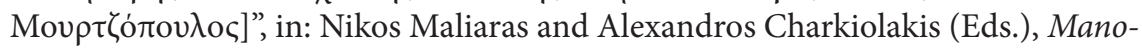
lis Kalomiris. 50 Years Later. Athens: Fagotto Books, 2013, 257-282.

33 Germany, Spain, Italy, and Greece (the 1936 Metaxas dictatorship) comprise the foremost examples of the 1930s. See: Katy Romanou, "Exchanging Rings under Dictatorships", op. cit., 30-32, 42-47.

34 A similar example, where a concerto serves as a representation of the composer's self-references comes from the American female composer Amy Beach (1867-1944). See: Adrienne Fried Block, “A 'Veritable Autobiography'? Amy Beach's Piano Concerto in C-sharp Minor, op. 45”, The Musical Quarterly, 78/2, 1994, 395, 397-398. 
Frangou-Psychopedis, Olympia: The National School of Music. Problems of Ideology $[H$

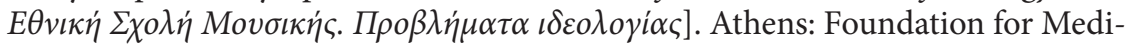
terranean Studies, 1990.

Fulias, Ioannis: “Rena Kyriakou's Concerto for Piano and Orchestra, Opus 18: Its History, a First Analytical Approach, a Critical Re-evaluation and an Attempt to

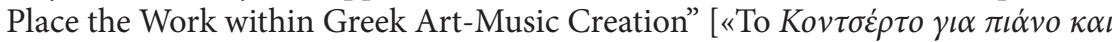

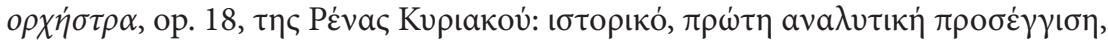

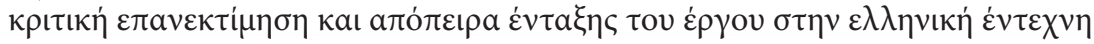

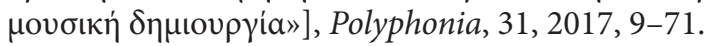

Hepokoski, James and Warren Darcy: Elements of Sonata Theory: Norms, Types, and Deformations in the Late-Eighteenth-Century Sonata. Oxford - New York: Oxford University Press, 2006.

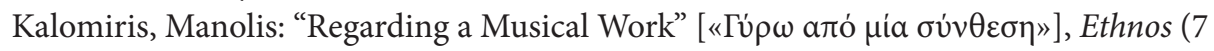
January 1955).

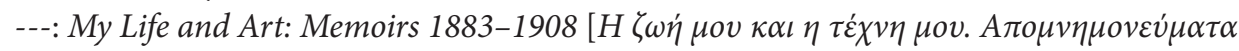
1883-1908]. Athens: Nefeli, 1988.

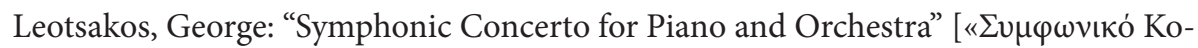

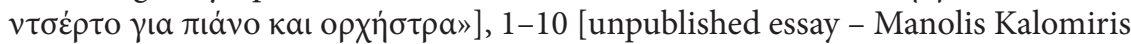
Society].

Lindeman, Stephan D.: “The Nineteenth-Century Piano Concerto”, in: Simon P. Keefe, The Cambridge Companion to the Concerto. Cambridge: Cambridge University Press, 2005, 93-117.

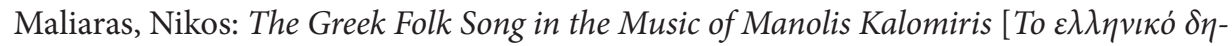

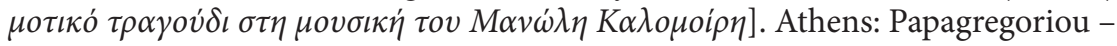
Nakas, 2001.

Romanou, Katy: "Exchanging Rings under Dictatorships", in: Roberto Illiano and Massimilliano Sala (Eds.), Music and Dictatorship in Europe and Latin America. Turnhout: Brepols, 2009, 27-64.

Sakallieros, Giorgos: “Perspectives of the Athenian Musical Life, 1870-1940”, in: Katrin Stoeck and Gilbert Stoeck (Eds.), Proceedings of the International Conference "Musik-Stadt. Traditionen und Perspektiven urbaner Musikkulturen". Band 4. Leipzig: Gudrun Schroeder Verlag, 2012, 94-104.

---: “The Greek Symphony (1900-1950): Oscillating Between Greek Nationalism and Western Art-Music Tradition", in: Nikos Maliaras (Ed.), Proceedings of the International Musicological Conference "The National Element in Music". Athens: University of Athens - Faculty of Music Studies, 2014, 31-49.

---: "Imitative Counterpoint in the Works of Dimitri Mitropoulos. Issues of Texture, In-

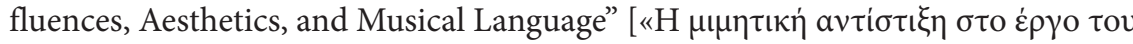

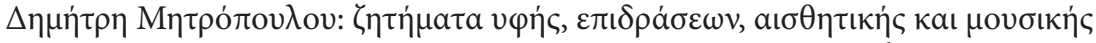
$\left.\gamma \lambda \omega \sigma \sigma a \varsigma^{\prime}\right]$, in: Kostas Chardas et al. (Eds.), Proceedings of the $8^{\text {th }}$ Interdepartmental Musicological Conference "Effetcs and Interactions". Thessaloniki: Hellenic Musicological Society, 2019, 233-256 [available online:

https://musicology.mus.auth.gr/wp-content/uploads/2019/04/ConfProc2016.pdf ]

Samson, Jim: Music in the Balkans. Leiden: Brill, 2013. 


\section{Summary}

The Symphonic Concerto for piano and orchestra (1935) occupies a prominent place in Manolis Kalomiris's compositional output as a representative example of a work providing a counterbalance of ostensibly heterogeneous components. Its complex and extensive symphonic texture, accompanied by a $19^{\text {th }}$ century-orientated grandiose and virtuosic piano part allows for the citation of modal folk material in the spirit and letter of the western canon (variation, thematic and harmonic elaboration, counterpoint, fugue). The symbolic portrayal of the composer's self-references underlines an inner autobiographical layout within the work, embraced by the Greek National School's ideological principles and the way Kalomiris envisions them. Such a context allows the composer to renegotiate the national-idea topos some twenty years after the School's foundation and prime, both aesthetically and musically. In this article, Kalomiris's Symphonic Concerto is examined from both its historical and analytical angles (often intermingling), through primary sources of music material (autograph manuscripts), notes from concert programmes, newspaper reviews, correspondence, and even unpublished papers by eminent Greek musicologists. The scrutinization of the score incorporates all the basic parameters of the music material, aiming at a more detailed commentary on the thematic and motivic areas and units, tonal and modal structures, idiomatic instrumental writing, use of orchestral color, and textural elements of the piano part. The morphological layout is outlined through both macroand micro structural viewpoints, being mindful of the existing documentation and giving answers on the work's oscillation between the genres of "symphony" and "concerto". Tables, musical examples and autograph manuscript material are included as complementary resources of interpreting the composer's compositional style and practice. The work is also examined both within Kalomiris's broader output and the contribution of other Greek composers to the genre of concerto in the first half of the $20^{\text {th }}$ century. Furthermore, the appearance of "concertante" works for piano and orchestra in European and American music from the late $19^{\text {th }}$ to the first decades of the $20^{\text {th }}$ century, either entitled or denoted as "symphonic" concertos, allows a comparative commentary on the use of folk material within the concerto genre and the employment of symbolic self-references as extrinsic to music resources. 